фактор оптимизации досуга населения: история, теория, практика. Барнаул, 2016. 199 с.

13. Сочиальный маркетинг // Тульчинский Г. Л. Менеджмент в сфере культуры. СанктПетербург, 2001. С. 141-158.

14. Годин А. М., Максимова Н. С., Подпорина И. В. Маркетинг. Москва, 2004. 728 с.

15. Смирнова Е. И. Теория и методика организации самодеятельного творчества трудящихся в культурно-просветительных учреждениях. Москва, 1983. 192 с.

16. Марков А. П. Проектирование маркетинговых технологий. Рекламные технологии. Связи с общественностью. Спонсорская деятельность. Ростов-на-Дону, 2006. 543 с.

17. Олейник Я. А. История Всероссийского фестиваля «Шукшинские дни на Алтае» в аспекте интеграции культурно-исторического наследия в сферу туризма // Мир науки, культуры, образования. 2014. № 6. С. 488-491.

18. Хороводные и игровые песни Сибири. Новосибирск, 1985. 246 с.

19. Даль В. И. Толковый словарь живого великорусского языка : [в 4 т.]. Москва. Т. 2. 1979.780 с. Из содерж.: Кострома С. 176.

УДК 001.895:[793.3:378.1](571.1)

DOI: $10.32340 / 2514-772 X-2020-1-69-72$

Г. В. Бурцева, кандидат педагогических наук, доцент Алтайский государственный институт культуры (Барнаул, Россия) burtseva-1957@mail.ru

\title{
К ИССЛЕДОВАНИЮ ХОРЕОГРАФИЧЕСКИХ НОВАЦИЙ В ОБРАЗОВАТЕЛЬНОМ ПРОСТРАНСТВЕ АЛТАЙСКОГО РЕГИОНА
}

Аннотация. Изложены предварительные результаты изучения эффективности внедрения экспериментальных хореографических новаций в образовательный процесс, организованный на хореографическом факультете Алтайского государственного института культуры (г. Барнаул Алтайского края, Россия) в рамках реализации многолетней научно-исследовательской и культурно-просветительной программы лаборатории «Мастерство хореографа», действующей на факультете. Освещены основные результаты работы регионального «круглого стола» по теме «Современный танец на Алтае: история, проблемы и перспективы развития» (Барнаул, 2019 г.), активными участниками которого стали ведущие преподаватели института в области современной хореографии, а также руководители современных профессиональных и любительских хореографических коллективов Алтайского края. В научный оборот впервые вводятся малоизвестные данные из истории становления и развития современного танца в регионе. Представлен авторский взгляд на основные направления дальнейшего научно-практического осмысления достижений современного танцевального искусства в регионе как вида хореографической новации в учебно-воспитательном процессе современной образовательной организации высшего образования.

Ключевые слова: новации в хореографии, хореографическое образование, современный танец, современное любительское хореографическое творчество, любительские хореографические коллективы, личные документные архивы.

На современном этапе в системе хореографического образования можно обнаружить две стратегии обучения: традиционную и инновационную (альтернативную). Бесспорным является тезис о том, что инновационный тип обучения и инновационная среда благоприятно влияют на проявление креативных свойств личности обучающегося, развитие разнообразных форм мышления (аналитического, проектного, концептуального и др.). Готовность к творческому сотрудничеству в новых ситуациях является важным профессиональным качеством выпускника-хореографа. Именно инно- вационная модель обучения стимулирует активный отклик на совместную проектную деятельность преподавателя и студента.

Опираясь на современную педагогическую парадигму и значимые для нас исследования в области теории и практике инноваций в плане управления и проектирования инновационных моделей профессионального обучения $[1,2]$. Опираясь на данные науки, авторский опыт развивает модель обучения бакалавров-хореографов в контексте инновационной методики преподавания хореографических дисциплин. Разработка и реали- 
зация модели инновационного обучения осуществляется в Алтайском государственном институте культуры с 2000 года. Инновационная методика связана с внедрением и разработкой содержания образовательного модуля «Современная хореография». Результаты подобной модели обучения представлены в ряде исследований автора, который выделил компоненты инновационнопроектировочной деятельности [3, 4].

Для открытия нового профиля потребовались долгие годы изучения потребностей хореографической практики в алтайском регионе, объективного оценочного отношения по поводу целесообразности обучения современным направлениям хореографии и воздействию инновационного модели на развитие и воспитание обучающихся. Полученные факты нашли отражения в многочисленных публикациях профессорско-преподавательского состава кафедры хореографии Алтайского государственного института культуры [5, 6]. На современном этапе педагоги-новаторы подводят некоторые итоги инновационной образовательной парадигмы, выявляют проблемы обучения и намечают перспективы дальнейшего развития после 20-летнего периода изучения образовательных ресурсов современного танца как учебного модуля в условиях творческого вуза.

Для этих целей на базе и при финансовой поддержке Алтайского государственного института культуры 29 мая 2019 г. была организована работа регионального «круглого стола» по теме «Современный танеи на Алтае: история, проблемы и перспективы развития». Мероприятие продолжило серию тематических «круглых столов», каждый из которых, по расчёту организаторов, позволяет внести весомый вклад в развитие историографии, теории и практики традиционного и современного танцевального искусства региона.

Подготовка к проведению тематического «круглого стола» велась в течение шести месяцев. Был разработан рабочий график мероприятия, перечень вопросов для обсуждения, программа. Вопросы рассматривались в контексте этапов развития современного танца и формирования содержания профессиональной модели хореографического образования по направлению подготовки «Танец и современная пластическая культура» в регионе, начиная с периода 90-х годов прошлого столетия:

1. Исторические предпосылки развития современного танца на Алтае.

2. Любительское хореографическое творчество в области современного танца на Алтае (начало пути):
- введение номинации «Современный танец» в программу краевых хореографических фестивалей-конкурсов;

- роль театра балета «Пространство любви» в становлении школы современного танца в краевой столице.

3. Первые опыты формирования репертуара на основе выразительных средств современного танца.

4. Подготовка специалистов-хореографов современного танца в Алтайском государственном институте культуры:

- роль ведущих педагогов-организаторов;

- первые педагоги на отделении;

- функции и задачи координатора программы обучения на современном этапе;

- научно-методологические подходы к обучению нового поколения педагогов в области современного танца;

5. Роль приглашенных педагогов, консультантов и экспертов направления подготовки.

6. Современный танец в системе обучения колледжей культуры и искусства:

- проблемы кадров и перспективы развития современного танца в Алтайском краевом колледже культуры и искусства;

- содержание программы обучения студентов современному танцу в Омском колледже культуры.

7. Значимые творческие проекты в системе обучения детей современному танцу в условиях любительских хореографических коллективов Алтайского края (история создания и развития, педагогические принципы и методика).

В работе круглого стола приняли участие руководители ведущих коллективов современного танца на Алтае:

- А. П. Ломова (образцовый хореографический ансамбль «Карамель», г. Барнаул);

- В. С. Лямина (образцовый коллектив Алтая ансамбль современного танца «Вдохновение», г. Барнаул);

- Л. В. Щербакова (образцовый детский самодеятельный коллектив России хореографический ансамбль «Соул», г. Барнаул);

- Т. В. Казанцева (образцовый коллектив России студия детского современного танца «Ласточка» г. Барнаул);

- О. М. Степура (образцовый коллектив Алтая ансамбль эстрадного танца «Ланце» г. Барнаул);

- О. А. Воробьева (образцовый коллектив театр-студия современного танца «ЮЛА», г. Новоалтайск); 
- Н. В. Казанцева, Е. А. Чеплыгина, О. С. Заркова (образцовая студия Заслуженного коллектива Алтайского края театра танца им. Розы Фибер, г. Барнаул);

- Н. В. Зотова (образцовый коллектив России театр-студия современного танца «ХамптиДампти», г. Барнаул);

- О. А. Половинкина (ансамбль современного и джазового танца «Ассорти», г. Барнаул);

- Н. В. Довгаль, О. В. Довгаль (образцовый коллектив России, театр танца «Натали», г. Барнаул);

- Г. А. Абрамова (театра-танца «Фиеста», г. Барнаул);

- М. В. Шульдякова (заслуженный коллектив Алтайского края ансамбль современного танца «Волшебный холст», г. Яровое);

- Т. А. Голубева (заслуженный коллектив Алтайского края «Калейдоскоп», г. Рубцовск);

- М. В. Паршукова, Т. Н. Третьякова (заслуженный коллектив Алтайского края, образцовый ансамбль современного танца «Серпантин», г. Рубцовск).

В рамках работы круглого стола педагогиорганизаторы новой хореографической профилизации Г. В. Бурцева, Л. В. Перлина, Н. И. Смолянинова, А. В. Пучков, О. А. Левицкая, О. А. Панковец поделились опытом становления специализации, рассказали о проблемах становления системы обучения на начальном этапе, о том, как формировался коллектив преподавателей, оттачивалась методика преподавания хореографических дисциплин, как постигались знания по содержанию новых учебных курсов в вузе.

Были вскрыты исторические предпосылки развития современного танца на Алтае. Анализ теоретических первоисточников на русском и английском языках вскрыл для практиков концептуальную идею современной хореографии и обнаружил наличие танцевальных техник, которые отсутствовали в традиционной системе обучения хореографическому творчеству. Подчеркнута роль гастролеров (театр А. Эйли, компания Тришы Браун и др.) в период 70-80-х годов XX века для развития информационного поля в области современной хореографии в России. Стали проводиться мастер-классы на базе созданных центров современной хореографии (Москва, Волгоград, Екатеринбург, Новосибирск, Красноярск и др.), которые активно посещали преподаватели вуза и практикихореографы из Алтайского края. Полученная информация постепенно внедрялась в хореографическую практику. В репертуаре любительских коллективов края в конце 80-х начале 90-х годов 20 столетия появлялись композиции на основе выразительных средств различных техник современ- ного танца. Это было началом долгого пути осознания педагогами-новаторами природы и эстетики современной хореографии.

Н. Н. Рябцева, которая долгие годы руководила организацией хореографических конкурсов в крае, рассказала, как с конца 80-х годов прошлого столетия развивалась и внедрялась в фестиваликонкурсы номинация «Современный танец», как акценты смещались в сторону стилизации различных видов танца, как содержание конкурсов наполнялось достойными произведениями современной хореографии.

Педагоги, которые работают на современном этапе в Алтайском государственном институте культуры Д. В. Голубев, К. Б. Дёмина раскрыли мотивы занятий и высказали свои ощущения о современном танце как образе жизни, что дает студентам этот вид хореографии для понимания телесности и развития концептуального мышления.

Далее О. Н. Вернигора рассказала как строится система занятий для студентов по новой образовательной программе «Танец и современная пластическая культура», подчеркнула роль приглашенных педагогов для совершенствования мастерства обучающихся: В. Ю. Никитина, доктора педагогических наук (Московский государственный университет культуры и искусств); А. И. Гурвич, заведующего кафедрой современной хореографии Екатеринбургского государственного университета; А. В. Любашина, преподавателя магистерской программы Санкт-Петербургской академии русского балета им. А.Я. Вагановой; А. А. Пестеревой, выпускницы магистерской программы Санкт-Петербургской академии русского балета им. А. Я. Вагановой, старшего преподавателя по дисциплине «Современный танец» Гимназии искусств и культуры (г. Москва).

Личные документные архивы руководителей хореографических коллективов позволили участникам ознакомиться с историей и авторскими методическими приемами обучения различным видам современного танца (джаз, модерн, контемпорари, контактная импровизация).

Важным направлением деятельности для участников круглого стола стала выработка дальнейшей перспективы развития современного хореографического пространства, методик изучения и исследования современного танца в Алтайском крае, что позволит собрать специалистам богатейший массив фактического материала из личных архивов. Эти обобщения опыта в дальнейшем будут использованы в качестве содержания важного раздела научной монографии «Хореографическое искусство в образовательном пространстве Алтайского края». 
По итогам работы «круглого стола» была принята резолюция. Заслушав и обсудив констатирующую часть резолюции, участники регионального «круглого стола» постановили:

1. Считать рабочие цели круглого стола достигнутыми: в ходе конструктивной дискуссии удалось затронуть целый ряд актуальных проблем теории и методики современного танца, обсудить ключевые вопросы истории современных направлений хореографии региона.

2. Предпринять необходимые усилия для популяризации в среде местных профессиональных педагогов-хореографов ценного в историкокультурном и педагогическом отношениях материала региональной методики преподавания и изучения современного танца.

3. Рекомендовать современным специалистам в области истории регионального хореографического искусства обратить своё исследовательское внимание на необходимость расширения предметного поля научных изысканий за счёт включения в научный оборот данных, полученных в результате обстоятельной паспортизации собранных исторических фактов о развитии современного танца на Алтае, а также рекомендовать преподавателям приобщать к самостоятельной поисковоаналитической работе, активному исследовательскому труду обучающихся образовательных организаций высшего и среднего профессионального образования в сфере культуры Алтайского края.

4. Для систематизации накопленных знаний о становлении и развитии современного танца рекомендовать ведущим специалистам в этой области ознакомиться с фактическим материалом, представленным участниками регионального «круглого стола», и дать экспертное заключение о полезности их включения в образовательные программы подготовки специалистов-хореографов в Алтайском крае.

5. Рекомендовать исследователям истории и современного состояния регионального современного хореографического искусства подготовить к публикации (в сборниках материалов конференций, сборниках научных статей, научных периодических изданиях, рецензируемых Высшей аттестационной комиссией) материалы, освещающие результаты научного исследования отдельных вопросов, затронутых в ходе работы «круглого стола».

6. Рекомендовать рабочей группе «круглого стола» провести необходимые административно- организационные мероприятия для расширения работы международного фестиваля-конкурса современного хореографического искусства «Образ» (на базе Алтайского государственного института культуры), нацеленного на демонстрацию творческих достижений танцевальных коллективов России и Алтайского края, выявление лучших зарубежных современных хореографических коллектиколлективов, повышение уровня исполнительской культуры в жанре современного хореографического искусства.

Участники «круглого стола» подтвердили готовность представляемых ими организаций к укреплению культурно-творческих связей и консолидации интеллектуального, кадрового, административного ресурсов для совместного решения важных научно-исследовательских задач. Гости мероприятия выражают свою благодарность коллективу преподавателей кафедры хореографии Алтайского государственного института культуры за организацию работы регионального «круглого стола».

Проект резолюции принят единогласно на итоговом собрании регионального «круглого стола» «Современный танец на Алтае: история, проблемы и перспективы развития» (29 мая 2019 г.).

\section{Список литературы}

1. Кваша В. П. Управление инновационными процессами в образовании : автореф. дис. ... канд. пед. наук: 13.00.01. Минск, 1994. 16 с.

2. Кларин М. В. Инновационные модели обучения в зарубежных педагогических поисках / М.В. Кларин. - Москва, 1994. - 222 с.

3. Буриева Г. В. Технология профессионального обучения педагога-хореографа в контексте инновационной деятельности. Барнаул, 2006. 315 с.

4. Бурцева Г. В. Методологические основания изучения инновационной деятельности специалиста-хореографа // Интеграционный потенциал профессиональной направленности в содержании социокультурного образования. Казань, 2003. C. 65-68.

5. Вернигора О.Н. Методика преподавания современных направлений в хореографии. Изд. 2-е., испр. и доп. Барнаул, 2018. 223 с.

6. Перлина Л. В. Танец модерн и методика его преподавания. Барнаул, 2009. 123 с. 